\title{
New specimen of Cacops woehri indicates differences in the ontogenetic trajectories among cacopine dissorophids
}

\author{
N. B. Fröbisch ${ }^{1}$, A. Brar ${ }^{2}$, and R. R. Reisz ${ }^{2}$ \\ ${ }^{1}$ Museum für Naturkunde, Leibniz Institut für Evolutions- und Biodiversitätsforschung, Invalidenstrasse 43, \\ 10115 Berlin, Germany \\ ${ }^{2}$ Department of Biology, University of Toronto at Mississauga, 3359 Mississauga Road N, Mississauga, ON L5L 1C6, Canada
}

Correspondence to: N. B. Fröbisch (nadia.froebisch@mfn-berlin.de)

Received: 28 October 2014 - Revised: 22 December 2014 - Accepted: 7 January 2015 - Published: 27 January 2015

\begin{abstract}
The Lower Permian Dolese locality has produced numerous exquisitely preserved tetrapod fossils representing members of a lower Permian upland fauna. Therein, at least nine taxa of the clade Dissorophoidea, ranging in size from the large predaceous trematopid Acheloma to the miniaturized amphibamid Doleserpeton, highlight the great taxic and ecological diversity of this anamniote clade. Here we describe a large specimen of the dissorophid Cacops woehri, which was previously only known from the juvenile or subadult holotype skull. Another member of the genus $\mathrm{Ca}$ cops present at the Dolese locality, Cacops morrisi, is also represented by specimens spanning juvenile, subadult, and adult stages, allowing for a comparison of morphological changes taking place in the late phases of the ontogenetic trajectory of cacopine dissorophids. The new find shows that, in contrast to $C$. morrisi and C. aspidephorus, C. woehri only undergoes relatively subtle changes in skull morphology in late ontogeny and retains the overall more gracile morphology into adult stages. This includes retention of the rather shallow skull shape as well as a pattern of sculpturing consisting of elongate ridges and grooves and a large occipital flange. This suggests somewhat different functional demands in $C$. woehri than in other known species of Cacops, possibly associated with a different ecology paralleling the great taxic diversity of dissorophoids at the Dolese locality.
\end{abstract}

\section{Introduction}

The Lower Permian Dolese Brothers Limestone Quarry locality near Richard Spur in Oklahoma is the most productive fossil site for Paleozoic terrestrial ecosystems, and has yielded more than 40 fully terrestrial tetrapod taxa, many of which are endemic to the locality (Anderson and Bolt, 2013; Anderson and Reisz, 2003; Bolt, 1969, 1977; Fröbisch and Reisz, 2008; Fröbisch and Reisz, 2012; Maddin et al., 2006; Reisz, 2005; Sullivan and Reisz, 1999; Sullivan et al., 2000). The vertebrate fossils are preserved in clay-rich continental sediments of Artinskian age (Lucas, 2006; Woodhead et al., 2010) that form infills within the Ordovician Arbuckle Limestone. The preservation of the fossils is extraordinary, both in terms of sheer number of specimens and the overall quality of preservation, and provides detailed insights into the anatomy of Permian tetrapods. The locality is considered to preserve an upland fauna, with the infills of the extensive cave system serving as natural traps for the vertebrate fauna inhabiting this upland environment (Reisz et al., 2009). The locality therefore complements data from wellknown Lower Permian lowland lacustrine localities (Reisz et al., 2009; Schoch, 2009). Within the Dolese fauna, members of the clade Dissorophoidea represent an important component of the tetrapod community with at least nine taxa known from this locality. They range in size from the miniaturized amphibamid Doleserpeton, with delicate bicuspid pedicelate teeth and an average skull length of about $1 \mathrm{~cm}$, to the large trematopid Acheloma, with dagger-like large teeth and an estimated skull length of about $20 \mathrm{~cm}$. Some taxa are known from fragmentary remains, or one or two specimens (Anderson and Bolt, 2013; Fröbisch and Reisz, 2008; Fröbisch 
and Reisz, 2012), while the amphibamid Doleserpeton occurs in copious amounts (Bolt, 1969; Sigurdsen and Bolt, 2010). Nevertheless, we see a greater taxic diversity of dissorophoids than in any other Paleozoic locality.

Dissorophoidea is a large clade that was very successful during the Paleozoic and continues to be so today, as most authors consider some or all three groups of modern amphibians to be part of Dissorophoidea (Anderson, 2008; Anderson et al., 2008b; Milner, 1988, 1993; Schoch and Milner, 2004; Sigurdsen and Green, 2011), but see, for example, Marjanović and Laurin (2013) for a different view. Recent phylogenetic analyses have recovered two distinct subclades within fossil dissorophoids, one comprising the Olsoniformes (dissorophids and trematopids) and one comprising the Xerodromes (amphibamids and branchiosaurids) (Anderson et al., 2008b; Fröbisch and Schoch, 2009; Schoch, 2012; Schoch and Milner, 2014). Amphibamids and branchiosaurids are represented by very small, miniaturized taxa which share a large number of characters with modern amphibians. While branchiosaurids were highly aquatic, amphibamids also include forms that were likely very terrestrial as metamorphosed adults (Schoch, 2009, 2010). Because of their central role in the controversial discussions surrounding the origin of modern amphibians, amphibamids and branchiosaurids have received much attention in the literature during the past 30 years, resulting in a quite detailed understanding of their diversity, biology, and phylogenetic relationships (Anderson and Bolt, 2013; Anderson et al., 2008a; Bourget and Anderson, 2011; Boy, 1972, 1986, 1987; Boy and Sues, 2000; Fröbisch and Reisz, 2008; Fröbisch and Schoch, 2009; Huttenlocker et al., 2007; Schoch, 2004; Schoch and Milner, 2008; Schoch and Rubidge, 2005; Werneburg, 2001, 2002, 2003). Unlike the small Xerodromes, olsoniforms are represented by rather large forms, some of which were heavily armored. They were likely highly terrestrial and predacious as post-metamorphic adults with an almost amniote-like ecology (Reisz et al., 2009; Schoch, 2009). Although they have been known from classic Permian deposits for over a century (Carroll, 1964; Demar, 1966, 1967, 1968; Romer, 1947; Williston, 1910, 1911), they did not receive much attention for some decades, and many taxa remain in need of taxonomic revision. Only in recent years have they received renewed interest, and the issues regarding their morphology, diversity, and relationships have been reevaluated through the restudy of known taxa and the discovery of new fossil material (Berman et al., 1985, 2009, 2011; Fröbisch and Reisz, 2012; Holmes et al., 2013; Maddin et al., 2010; May et al., 2011; Polley and Reisz, 2011; Reisz et al., 2009; Schoch, 2012; Schoch and Sues, 2013).

For some Paleozoic amphibians, extensive ontogenetic series are preserved, providing important insights into their development and growth (Fröbisch et al., 2010; Schoch, 2004, 2009, 2014; Witzmann and Pfretzschner, 2003; Witzmann and Schoch, 2006a, b). In particular, thanks to the

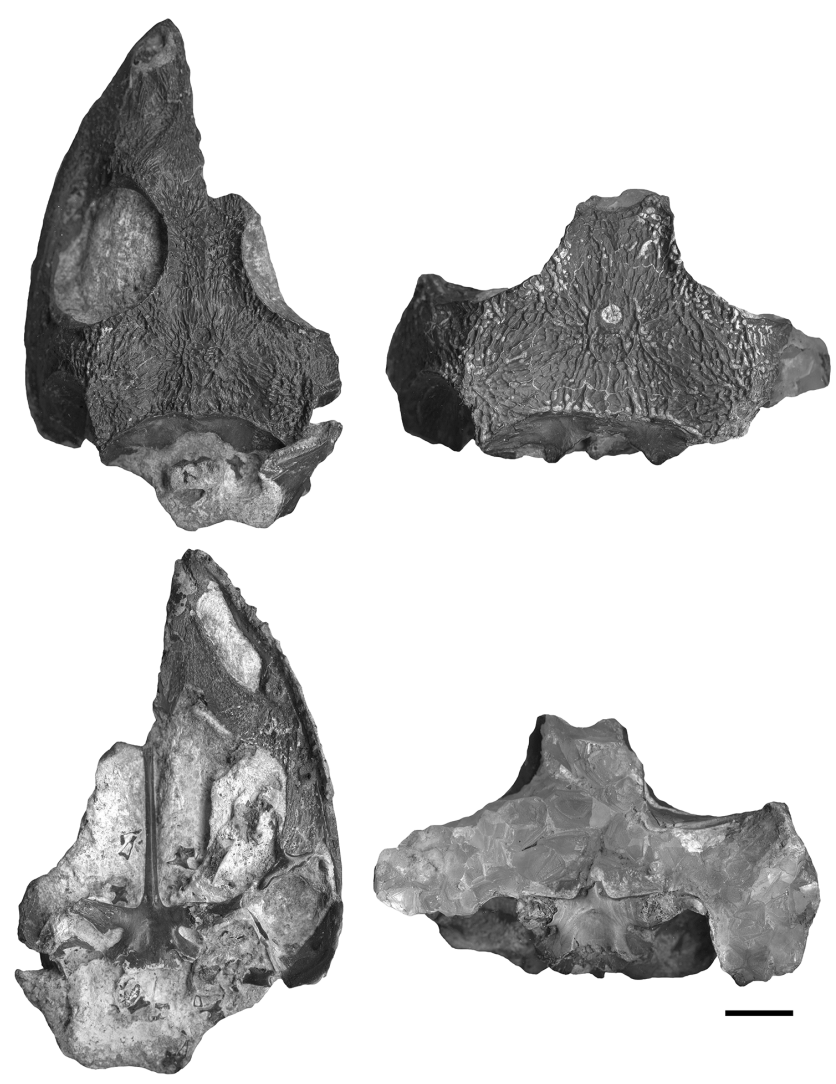

Figure 1. Side-by-side photos of the holotype OMNH 73216 (left) and referred specimen BMRP 2007.3.5 (right) of Cacops woehri in dorsal (top) and palatal (bottom) view.

excellent preservational conditions in the lakes that these taxa inhabited, micromelerpetontid and branchiosaurid dissorophoids have been studied extensively. Because of their phylogenetic significance amphibamid ontogeny (Schoch, 2009) has also attracted attention. However, much less is known about the ontogeny of the olsoniforms. Evidence from the trematopid Mordex suggests that at least some olsoniforms had an aquatic larva very similar to branchiosaurids and amphibamids, and that they underwent a drastic metamorphosis into a terrestrial adult (Milner, 2007; Schoch, 2009), but further details of the larval ecology and developmental trajectories of olsoniforms remain largely elusive. Here we describe a new specimen of the dissorophid $\mathrm{Ca}$ cops woehri from the Dolese deposits which is $25 \%$ larger than the previously described holotype (Fröbisch and Reisz, 2012) (Fig. 1). This new specimen confirms the taxic identity of this species, and is distinct from another species of Cacops from this locality, Cacops morrisi. The presence of two very closely related terrestrial taxa in the same locality is a rare occurrence in the Paleozoic, and is worthy of detailed examination. Cacops morrisi is known from several skulls, with a size range of about $33 \%$ (Reisz et al., 2009). This allows for a comparison of the late phases of ontogeny 
in two closely related species and provides new insights into anatomical changes throughout the ontogenetic trajectories of olsoniform dissorophoids.

\section{Systematic paleontology}

Temnospondyli Zittel, 1888

Dissorophoidea Bolt, 1969

Olsoniformes Anderson et al., 2008a

Dissorophidae Boulenger, 1902

Cacops Williston, 1910

Type species. Cacops aspidephorus Williston, 1910, by original designation.

Diagnosis. Dissorophid temnospondyl with a more or less pronounced pattern of bony ridges and depressions along the skull roof, snout, and sides of the skull; nasal with near horizontal anterior portion and dorsally arching posterior portion; posteriorly foreshortened skull roof. Large, concave lateral exposure of the palatine (LEP) positioned along the anteroventral edge of the orbit. Contact between ventral process of the tabular and the dorsal process of the quadrate closes tympanic region posteriorly in adult specimens.

\section{Cacops woehri Fröbisch and Reisz, 2012}

Type locality and horizon. Dolese Brothers Limestone Quarry near Richard Spur, SW 1/4 section 31, T4N, R11W, Comanche County, Oklahoma, USA.

Material/referred specimens. Holotype OMNH 73216 and new referred specimen BMRP 2007.3.5.

Revised diagnosis. Species of the genus Cacops that differs from C. aspidephorus and C. morrisi in the lack of the tall, boxy skull in the temporal region; has instead a rather shallow skull shape that is retained in adults; more dorsally located orbits and an "L-shaped" opening of the tympanic embayment. The sculpturing pattern consists of characteristic radial ridges and grooves that become only slightly more pronounced in adult individuals.

\section{Description of large specimen BMRP 2007.3.5}

The new specimen of Cacops woehri BMRP 2007.3.5 consists of a partial skull that preserves the posterior skull roof and interorbital region, left cheek region, and parts of the palatal region (Figs. 2-4). Although incomplete, the skull bones of the specimen are very well preserved and show sutural patterns and dermal sculpturing in fine detail.

Cacops woehri was previously known from a single specimen, a well-preserved skull that was considered to represent a juvenile or subadult individual (Fröbisch and Reisz, 2012) because of its relatively small size and the pattern of sculpturing. This can now be corroborated based on the new specimen of $C$. woehri (BMRP 2007.3.5.) from the same locality,

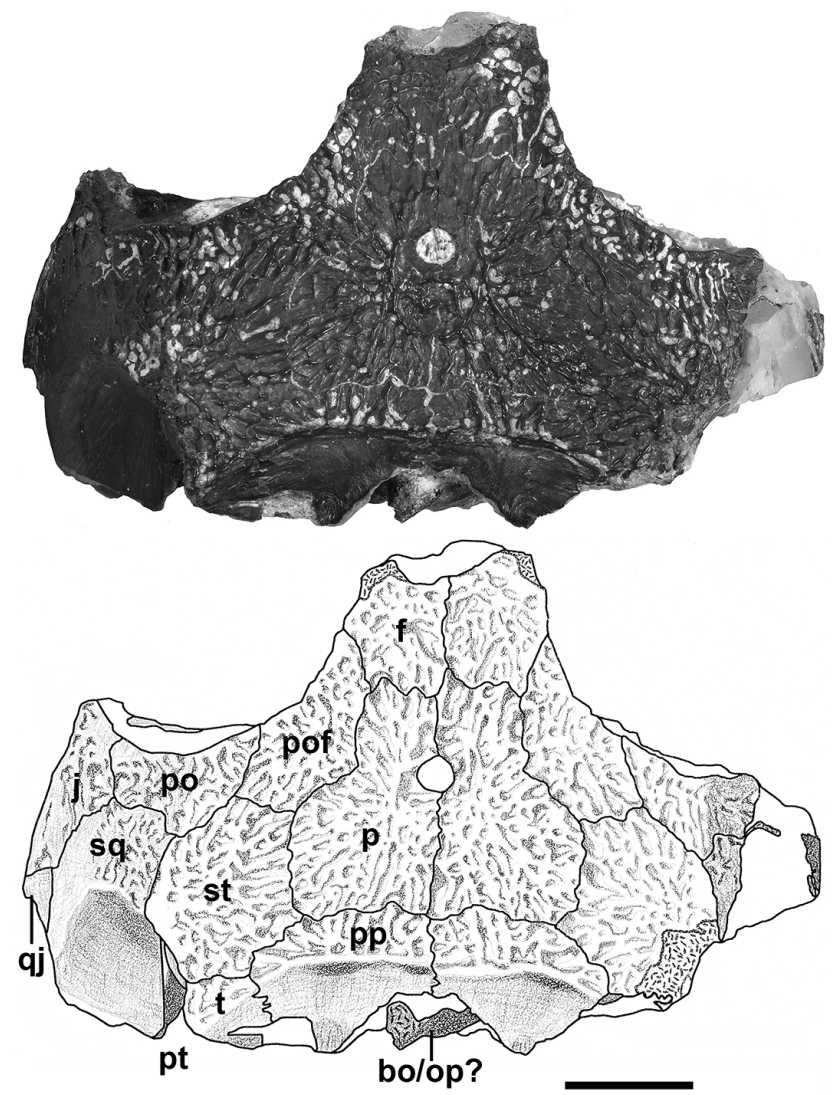

Figure 2. Photo and drawing of the skull of the new specimen of Cacops woehri BMRP 2007.3.5 in dorsal view. Scale bar equals $1 \mathrm{~cm}$.

which is $25 \%$ larger than the holotype. The holotype measures $11 \mathrm{~mm}$ from the posterior end of the pineal foramen to the occipital rim, compared to $14 \mathrm{~mm}$ in the new referred specimen. The width of the skull table measured from side to side of the lateral edge of the supratemporal boss is $37.5 \mathrm{~mm}$ in the holotype versus $50 \mathrm{~mm}$ in BMRP 2007.3.5. The interorbital width at the level of the postfrontal-frontal contact at the orbit amounts to $12.5 \mathrm{~mm}$ in the holotype and $17 \mathrm{~mm}$ in the referred specimen BMRP 2007.3.5.

Overall the resemblance between the two specimens is striking, with very few morphological changes aside from the significant size difference. The anterior portion of the frontals of BMRP 2007.3.5 is not preserved, but their posterior portion indicates that they had a rather slender, rectangular shape as also seen in the holotype of $C$. woehri. They make contact with the parietals posteriorly in an interdigitating suture and posterorlaterally contact the postfrontals along the rim of the orbit (Figs. 2,3). The parietals are well preserved and enclose a round pineal foramen. Their anterior portion is rather narrow, but they flare out laterally at the level of the pineal foramen, so that the posterior part is significantly wider than the anterior region. This shape of the parietals is also seen in the holotype of $C$. woehri, as well as in the ju- 


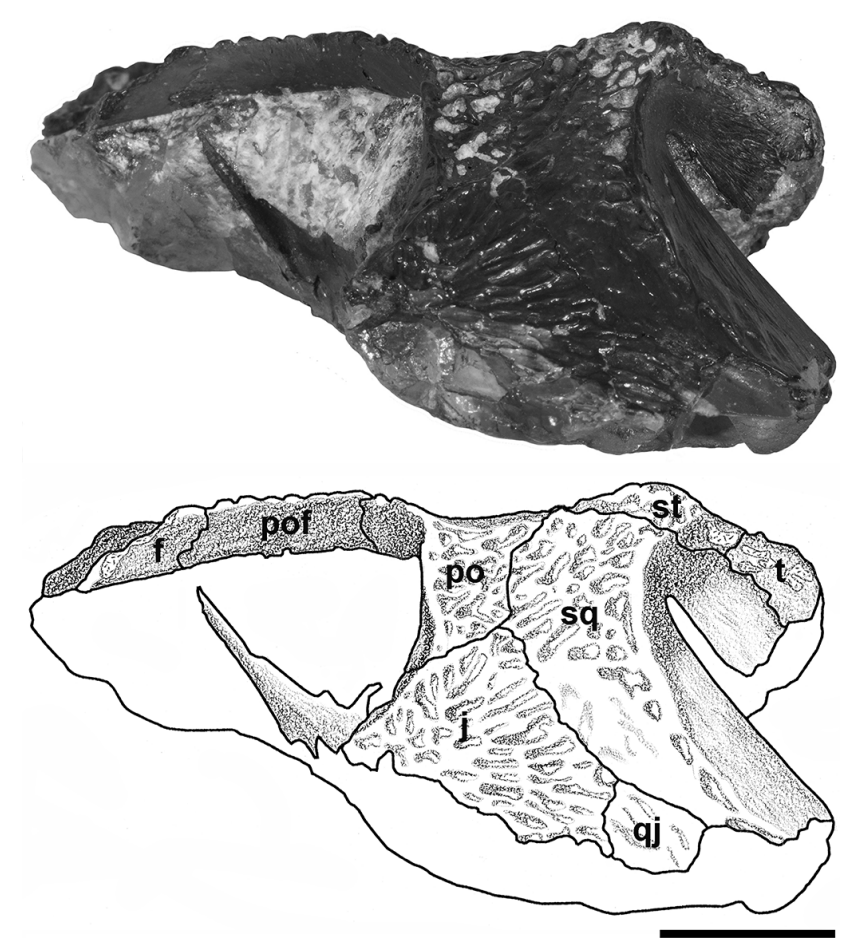

Figure 3. Photo and drawing of the skull of the new specimen of Cacops woehri BMRP 2007.3.5 in left lateral view. Scale bar equals $1 \mathrm{~cm}$.

venile and adult specimens of $C$. morrisi (Reisz et al., 2009). Anterolaterally, the parietal has a well-defined suture with the postfrontal, while posterolaterally these two make contact with the supratemporal. Posteriorly, they are bordered by the postparietals, which they contact in a slightly interdigitating, transversely orientated suture. The postparietals consist of a short and wide dorsal portion that forms the posteriormost part of the skull table and bears pronounced dermal sculpturing (Fig. 2). This dorsal portion of the postparietal is demarcated from a smooth ventrally sloping occipital flange by a pronounced and slightly elevated occipital rim. The occipital flanges of the postparietals are large and roughly triangular in shape. They enclose an arched opening, in which elements of the occipital region are visible, but not clearly identifiable (Fig. 2).

The postfrontals are broadly crescent shaped and form the posterordorsal rim of the orbit. In contrast to the holotype, they lack the long and slender posterolateral process which wedges in between the postorbital and the supratemporal. Instead, they make contact with the supratemporal posteriorly in a rather short, straight suture (Fig. 2). Due to the absence of the posterior process of the postfrontal, the postorbital has a broader sutural contact with the supratemporal than in the juvenile holotype of Cacops woehri. In the holotype, the contact between postorbital and supratemporal is minute, while in C. morrisi the two elements do not make contact at all, neither in the juvenile nor in the adult specimen (Reisz et al., 2009). In the large specimen of $C$. woehri, the postorbital has the shape of a blunt triangle that forms the posterior rim of the orbit. Its posterolateral side makes contact with the squamosal and laterally it is flanked by the jugal. The squamosal is a large element and as typical for dissorophoids, forms a significant part of the temporal and otic regions of the skull. It consists of a sculptured dorsal and lateral part that contacts the supratemporal dorsally, the postorbital and jugal laterally, and quadratojugal ventrolaterally. Moreover, it has a steeply sloping, smooth squamosal flange that encloses a narrow, elongate gap in the otic region. Dorsolaterally it makes contact with the supratemporal and the tabular, which contribute to the smooth dorsal part of the squamosal embayment, the semilunar flange (Fig. 3).

The small tabular bone forms the posterolateral corner the skull table. It contributes to the skull roof with a small sculptured area, and posteriorly continues in a ventrally oriented, smooth flange that forms the lateral parts of the large occipital flange (Fig. 2). Laterally, the tabular also has a ventrally oriented smooth portion that forms the posterodorsal part of the otic region. Unfortunately, the tabular is not completely preserved posterolaterally and it remains uncertain as to whether it had a pronounced ventral projection as seen in the holotype of Cacops woehri or even approached or made contact with the quadrate as seen in adults of Cacops morrisi (Reisz et al., 2009). Overall, however, the preserved parts of the otic region in the new specimen are remarkably similar to the juvenile holotype and enclose a narrow gap in between the two smooth flanks of the squamosal (Fig. 3).

The jugal contributes significantly to the cheek region with a large, triangular dorsal process that contacts the postorbital anterodorsally and the squamosal posterolaterally. Its ventral portion is broken and it is uncertain whether an anterior process extended along the posteroventral rim of the orbit as seen in the holotype. Only a small part of the quadratojugal is preserved in the large specimen of $C$. woehri at the posteroventral edge of the cheek region. It wedges in between the jugal anteriorly and the squamosal posteriorly.

The preserved palatal region of specimen BMRP 2007.3.5 is filled with large calcite crystals (Fig. 4). Only the pentagonal basal plate of the parasphenoid is preserved, and it shows robust lateral processes for the basicranial articulation with the pterygoids. The carotid foramina are rather large, oval, and located at the base of the cultriform process. Medially, the basal plate bears a semilunate, depressed area that probably served for muscle attachment.

\section{Discussion}

The exceptional preservation at this locality allows for a comparison of the late stages of ontogeny in two closely related species of dissorophids, namely Cacops woehri and $\mathrm{Ca}$ cops morrisi. Unfortunately, the material of the third species of Cacops, Cacops aspidephorus, is encrusted in hard iron 


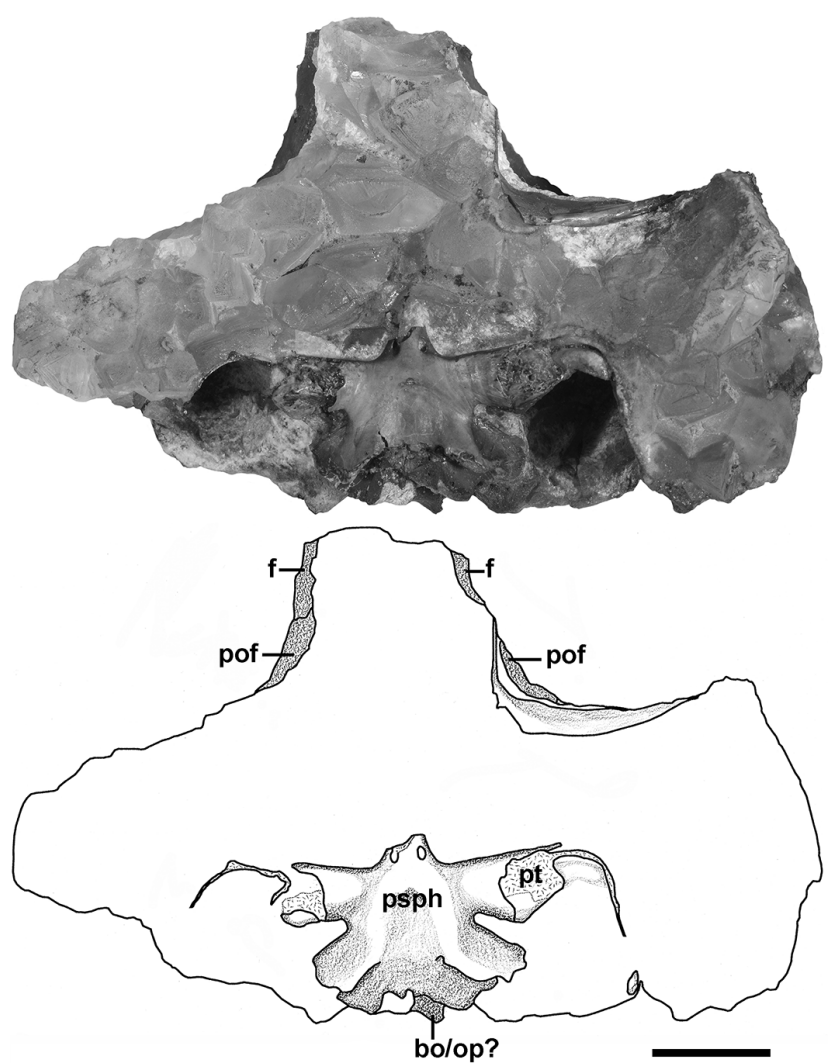

Figure 4. Photo and drawing of the skull of the new specimen of Cacops woehri BMRP 2007.3.5 in ventral view. Scale bar equals $1 \mathrm{~cm}$.

stone and only poorly preserved, hindering detailed anatomical comparisons with the two Dolese species (Fröbisch and Reisz, 2012; Reisz et al., 2009; Schoch, 2012; Williston, 1910). Cacops morrisi represents the typical morphology as classically associated with the genus Cacops, which is also present in the type species Cacops aspidephorus despite its overall much poorer preservation. Most prominently, this includes the massive, rectangular box shape of the skull roof and the pronounced sculpturing of the dermal skull bones. Distinct ridges along the edges of the temporal regions and along the snout region add to the distinctive morphology of the Cacops skull. The most juvenile specimen of $C$. morrisi is one-third smaller than the largest, presumably adult specimen, and notable ontogenetic changes take place along their ontogenetic trajectory (Reisz et al., 2009). The shallower skull shape of the juvenile becomes significantly boxier in the adult stage, which is paralleled by an increase in dermal sculpturing. While the sculpturing is more shallow and certain regions of the skull in the smallest juvenile such as the sides of the snout and the frontal and jugal regions are almost smooth, the ornamentation becomes heavier and deeper in the adult and is evenly distributed over the dermal skull elements. Moreover, the smallest specimen of C. morrisi shows a laterally exposed ectopterygoid at the ventral rim of the orbit, which is not present in the adult individual, and among other dissorophids is only seen in Scapanops neglecta (Schoch and Sues, 2013). Its presence in the juvenile specimen of $C$. morrisi is reminiscent of the condition seen in trematopids (Polley and Reisz, 2011; Reisz et al., 2009). An additional, profound change takes place in the otic region of C. morrisi with the posterior closure of the squamosal embayment. This is achieved by a contact between the ventral process of the tabular and the dorsal process of the quadrate, which in the juvenile are still separated by a large gap. However, a third, intermediate sized skull of $C$. morrisi still lacks the contact, suggesting that the otic closure occurred only in the latest stages of ontogeny.

The available ontogenetic data for $C$. woehri are somewhat less complete than for $C$. morrisi due to the fewer number of known skulls, and the incomplete preservation of the presumed adult specimen BMRP 2007.3.5. Nevertheless, the data at hand allow for a comparison of the ontogenetic trajectories of the two Cacops species and indicate that the changes in $C$. woehri are much less pronounced than in $C$. morrisi. The overall skull shape of $C$. woehri is much shallower than in even the juvenile $C$. morrisi, and significantly more so than in the adults of $C$. morrisi and $C$. aspidephorus. Judging from the preserved region of BMRP 2007.3.5, the overall skull shape did not change in shape significantly, indicating that a comparatively shallow skull shape was indeed a characteristic feature of Cacops woehri that sets it apart from the other two species of the genus. Similarly, there is no drastic change in ornamentation between the juvenile and the large specimen of $C$. woehri. In contrast, the distribution and the pattern of elongated radial ridges and grooves is almost identical in both specimens and only appears scaled up in size, but not intensity, in the large specimen (Fig. 1). An almost ornamentation-free region along the jugal-squamosal suture in the cheek region is still present in the large specimen (Fig. 3), unlike C. morrisi, where regions of the skull that are smooth in the juvenile are heavily ornamented in the adult (Reisz et al. 2009). Unfortunately, the otic region is not fully preserved in the large specimen of C. woehri, and therefore it is not possible to determine whether a posterior closure of the squamosal embayment took place in this species. The preserved parts of the otic region, i.e., the squamosal enclosing a narrow transversely oriented gap and the sutural patterns with the supratemporal and tabular, are remarkably similar in the two specimens. A few anatomical changes are, however, visible between the two specimens of $C$. woehri. One is seen in the sutural patterns of the postorbital bone with the neighboring skull elements. In the juvenile specimen the postfrontal has a long and slender posterior process that wedges in between postorbital and the supratemporal, leaving only a minute contact between the latter two elements. This posterior process of the postfrontal is absent in the large specimen, which shows a fairly long suture between the posterodorsal side of the postorbital and the anterolateral side of the supratemporal (Figs. 1, 2). Although in C. morrisi, 
the postorbital does not contact the supratemporal in either the juvenile or the adult specimen (Reisz et al., 2009), there is some shape change during ontogeny, with the posterolateral process of the postfrontal becoming wider, and creating a wider sutural gap between the postorbital and the supratemporal. Another change can be seen in extent of the smooth occipital flange made up of the posteroventral parts of the postparietals and tabulars. In the juvenile of $C$. woehri, the occipital flange is already significantly larger than in either ontogenetic stage of $C$. morrisi, and increases even more in size in the large specimen BMRP 2007.3.5. A difference in shape is also visible in the parasphenoid basal plate. While the overall morphology stays constant in $C$. woehri, the basal plate of the large specimen is somewhat shorter and wider than in the juvenile, possibly indicating a change in skull proportions towards a shorter posterior skull table in the large animal (Fig. 4).

The much shallower skull of $C$. woehri relative to the other two Cacops species, C. aspidephorus and C. morrisi, is the most obvious and pronounced difference setting this species apart, and the new specimen shows that this is retained into late ontogenetic stages. Together with the extremely large occipital flange, it is suggestive of different functional demands, e.g., associated with a different feeding ecology. This, however, will have to remain somewhat speculative until additional specimens of this species become available. Nevertheless, the overall differences between the two species of Cacops correlates well with the overall more gracile, delicate morphology of the skull and teeth of $C$. woehri, as well as the more heavily ornamented, more massively constructed skull and slightly more robust teeth of $C$. morrisi.

The large taxic and morphological diversity seen in dissorophids suggests that they were a very successful group and new finds and the recent restudy of historic material have revealed a much greater ecological diversity than previously known (Bolt, 1977; Carroll, 1964; Demar, 1966, 1967, 1968; Fröbisch and Reisz, 2008; Reisz et al., 2009; Schoch, 2012; Schoch and Sues, 2013; Williston, 1910). Even the limited data set at hand in terms of growth stages in dissorophids indicates that this diversity is in parts established in and achieved through somewhat different ontogenetic trajectories. This supports the notion that, during the upper Carboniferous and Permian, dissorophids represented important faunal elements of terrestrial vertebrate communities, and were highly successful terrestrial predators alongside the reptiles and synapsids of their time. Their significance is underscored by the evidence provided by the Dolese fauna, with a staggering, and yet still increasing, taxic and ecological diversity in this fully terrestrial assemblage. For reasons yet unknown, the olsoniform lineage disappears towards the end of the Permian, leaving only the amphibamid/branchiosaurid lineage within dissorophoids to continue their successful evolutionary history into recent times.
Institutional abbreviations: OMNH, Oklahoma Museum of Natural History, USA; BMRP, Burpee Museum of Natural History, USA.

Anatomical abbreviations: bo/op?, basioccipital/opisthotic; f, frontal; j, jugal; p, parietal; po, postorbital; pof, postfrontal; pp, postparietal; psph, parasphenoid; pt, pterygoid; qj, quadratojugal; sq, squamosal; st, supratemporal; t, tabular.

Acknowledgements. We would like to thank Scott Williams of the Burpee Museum, Rockford, NJ, for allowing us to borrow, prepare, and study this specimen, and Diane Scott for helping with the preparation, photography, and illustrations of the specimen. Jason Anderson and Hillary Maddin are thanked for their insightful comments, which greatly helped to improve this manuscript. Research was supported by an Emmy Noether Grant of the German Research Foundation (FR 2647/5-1) to N. B. Fröbisch and a NSERC Discovery Grant to R. R. Reisz. We would also like to thank William May and other colleagues at the Sam Noble Museum of Natural History for their continued support of our research on the Dolese fauna.

Edited by: D. Korn

Reviewed by: J. Anderson and H. Maddin

\section{References}

Anderson, J. S.: Focal review: The origin(s) of modern amphibians, Evol. Biol., 35, 231-247, 2008.

Anderson, J. S. and Bolt, J. R.: New Information on Amphibamids (Tetrapoda, Temnospondyli) from Richards Spur (Fort Sill), Oklahoma, J. Vertebr. Paleontol., 33, 553-567, 2013.

Anderson, J. S., Henrici, A., Sumida, S. S., Martens, T., and Berman, D. S.: Georgenthalia clavinasica, a new genus and species of dissorophoid temnospondyl from the early Permian of Germany, and the relationships of the family Amphibamidae, J. Vertebr. Paleontol., 28, 61-75, 2008a.

Anderson, J. S. and Reisz, R. R.: A new microsaur (Tetrapoda: Lepospondyli) from the Lower Permian of Richards Spur (Fort Sill), Oklahoma, Can. J. Earth Sci., 40, 499-505, 2003.

Anderson, J. S. and Reisz, R. R. Pyozia mesenensis, a new small varanopid (Syapsida, Eurepelycosauria) from Russia: "pelycosaur" diversity in the middle Permian, J. Vertebr. Paleontol., 24, 173-179, 2004.

Anderson, J. S., Reisz, R. R., Fröbisch, N. B., Scott, D., and Sumida, S. S.: A stem batrachian from the Early Permian of Texas and the origin of frogs and salamanders, Nature, 453, 515-518, $2008 \mathrm{~b}$.

Berman, D. S., Henrici, A. C., Brezinski, D. K., and Kollar, A. D.: A New Trematopid Amphibian (Temnospondyli: Dissorophoidea) from the Upper Pennsylvanian of Western Pennsylvania: Earliest Record of Terrestrial Vertebrates Responding to a Warmer, Drier Climate, Ann. Carnegie Mus., 78, 289-318, 2009.

Berman, D. S., Henrici, A. C., Martens, T., Sumida, S. S., and Anderson, J. S.: Rotaryus gothae, a New Trematopid (Temnospondyli: Dissorophoidea) from the Lower Permian of Central Germany, Ann. Carnegie Mus., 80, 49-65, 2011.

Berman, D. S., Reisz, R. R., and Eberth, D. A.: Ecolsonia cutlerensis, an early Permian dissorophid amphibian from the Cutler For- 
mation of north-central New Mexico, New Mexico Bureau of Mines and Mineral Resources Circular, 191, 1-31, 1985.

Bolt, J. R.: Lissamphibian origins: possible protolissamphibian from the Lower Permian of Oklahoma, Science, 166, 888-891, 1969.

Bolt, J. R.: Cacops (Amphibia: Labyrinthodontia) from the Fort Sill locality, Lower Permian of Oklahoma, Fieldiana, Geology, 37, 61-73, 1977.

Bourget, H. and Anderson, J. S.: A New Amphibamid (Temnospondyli: Dissorophoidea) from the Early Permian of Texas, J. Vertebr. Paleontol., 31, 32-49, 2011.

Boy, J. A.: Die Branchiosaurier (Amphibia) des saarpfaelzischen Rotliegenden (Perm, SW-Deutschland), Abhandlungen des hessischen Landesamt fuer Bodenforschung, 65, 6-137, 1972.

Boy, J. A.: Studien über die Branchiosauridae (Amphibia: Temnospondyli) 1. Neue und wenig bekannte Arten aus dem mitteleuropäischen Rotliegenden (?oberstes Karbon bis unteres Perm), Palaeont. Z., 60, 131-166, 1986.

Boy, J. A.: Studien über die Branchiosauridae (Amphibia: Temnospondyli; Ober-Karbon - Unter-Perm. Systematische Übersicht, Neues Jahrbuch für Geologie und Paläontologie Abhandlungen, 174, 75-104, 1987.

Boy, J. A. and Sues, H.-D.: Branchiosaurs: Larvae, metamorphosis and heterochrony in temnospondyls and seymouriamorphs, in: Amphibian Biology, edited by: Heatwole, H. and Carroll, R. L., Volume 4, Surrey Beatty and Sons PTY limited, Chipping Norton, 1150-1197, 2000.

Carroll, R. L.: Early evolution of the dissorophoid amphibians, Bulletin of the Museum of Comparative Zoology, 131, 161-250, 1964.

Demar, R.: The Permian labyrinthodont amphibian Dissorophus multicinctus, and adaptations and phylogeny of the family Dissorophidae, J. Paleontol., 42, 1210-1242, 1968.

Demar, R. E.: The phylogenetic and functionl implications of the armor of the Dissorophidae, Fieldiana, Geology, 16, 55-88, 1966.

Demar, R. E.: Two new species of Broiliellus (Amphibians) from the Permian of Texas, Fieldiana, Geology, 16, 117-129, 1967.

Fröbisch, N. B., Olori, J. C., Schoch, R. R., and Witzmann, F.: Amphibian development in the fossil record, Seminars in Cell and Developmental Biology, 21, 424-431, 2010.

Fröbisch, N. B. and Reisz, R. R.: A new Lower Permian amphibamid (Dissorophoidea, Temnospondyli) from the fissure fill deposits near Richards Spur, Oklahoma, J. Vertebr. Paleontol., 28, 1015-1030, 2008.

Fröbisch, N. B. and Reisz, R. R.: A new species of dissorophid (Cacops woehri) from the Lower Permian Dolese Quarry, near Richards Spur, Oklahoma, J. Vertebr. Paleontol., 32, 35-44, 2012.

Fröbisch, N. B. and Schoch, R. R.: Testing the impact of miniaturization on phylogeny: Paleozoic dissorophoid amphibians, Syst. Biol., 58, 312-327, 2009.

Holmes, R. B., Berman, D. S., and Anderson, J. D.: A new dissorophid (Temnospondyli, Dissorophoidea) from the Early Permian of New Mexico (United States), C. R. Palevol, 12, 419-435, 2013.

Huttenlocker, A. K., Pardo, J. D., and Small, B. J.: Plemmyradytes shintoni, gen. et sp. nov., an Early Permian amphibamid (Temnospondyli: Dissorophoidea) from the Eskridge Formation, Nebraska, J. Vertebr. Paleontol., 27, 316-328, 2007.
Lucas, S. G.: Global Permian tetrapod biostratigraphy and biochronology, edited by: Lucas, S. G., Cassinis, G., and Schneider, J. W., in: Non-marine Permian biostratography and biochronology, Volume 265, Geological Society of London, London, 65-93, 2006.

Maddin, H. C., Evans, D. C., and Reisz, R. R.: An early Permian varanodontine varanopid (Synapsida: Eupelycosauria) from the Richard Spurs locality, Oklahoma, J. Vertebr. Paleontol., 26, 957-966, 2006.

Maddin, H. C., Reisz, R. R., and Anderson, J. S.: Evolutionary development of the neurocranium in Dissorophoidea (Tetrapoda: Temnospondyli), an integrative approach, Evol. Dev., 12, 393403, 2010.

Marjanović, D. and Laurin, M.: The origin(s) of extant amphibians: a review with emphasis on the "lepospondyl hypothesis", Geodiversitas, 35, 207-272, 2013.

May, W., Huttenlocker, A. K., Pardo, J. D., Benca, J., and Small, B. J.: New Upper Pennsylvanian armored dissorophid records (Temnospondyli, Dissorophoidea) from the U.S. midcontinent and the stratigraphic distributions of dissorophids, J. Vertebr. Paleontol., 31, 907-912, 2011.

Milner, A. R.: The relationships and origin of living amphibians, edited by: Benton, M. J., in: The phylogeny and classification of the tetrapods, Volume 1, Clarendon Press, Oxford, 59-102, 1988.

Milner, A. R.: The Paleozoic relatives of lissamphibians, Herpetol. Monogr., 7, 8-27, 1993.

Milner, A. R.: Mordex laticeps and the base of the Trematopidae, J. Vertebr. Paleontol., 27, 118A, 2007.

Polley, B. P. and Reisz, R. R.: A new Lower Permian trematopid (Temnospondyli: Dissorophoidea) from Richards Spur, Oklahoma, Zool. J. Linn. Soc.-Lond., 161, 789-815, 2011.

Reisz, R. R.: Oromycter, a new caseid from the Lowen Permian of Oklahoma, J. Vertebr. Paleontol., 25, 905-910, 2005.

Reisz, R. R., Schoch, R. R., and Anderson, J. S.: The armoured dissorophid Cacops from the Early Permian of Oklahoma and the exploitation of the terrestrial realm by amphibians, Naturwissenschaften, 96, 789-796, 2009.

Romer, A. S.: Review of the Labyrinthodontia, Bulletin of the Museum of Comparative Zoology, 99, 1-352, 1947.

Schoch, R.: Heterochrony: the interplay between development and ecology exemplified by a Paleozoic amphibian clade, Paleobiology, 36, 318-334, 2010.

Schoch, R. R.: Skeleton formation in the Branchiosauridae: A case study in comparing ontogenetic trajectories, J. Vertebr. Paleontol., 24, 309-319, 2004.

Schoch, R. R.: Evolution of life cycles in early amphibians, Annu. Rev. Earth Pl. Sc., 37, 135-162, 2009.

Schoch, R. R.: Character distribution and phylogeny of the dissorophid temnospondyls, Foss. Rec., 15, 121-137, doi:10.5194/fr-15-121-2012, 2012.

Schoch, R. R.: Life cycles, plasticity and palaeoecology in temnospondyl amphibians, Palaeontology, 57, 517-529, 2014.

Schoch, R. R. and Milner, A.: Handbook of Paleoherpetology, Temnospondyli I, Dr. Friedrich Pfeil, Munich, Germany, 2014.

Schoch, R. R. and Milner, A. R.: Structure and implications of theories on the origins of lissamphibians, edited by: Arratia, G. and Wilson, M. V. H., Recent advances in the origin and early radiation of vertebrates, Verlag Dr. Friedrich Pfeil, Munich, 345-377, 2004. 
Schoch, R. R. and Milner, A. R.: The intrarelationships and evolutionary history of the temnospondyl family Branchiosauridae, J. Syst. Palaeontol., 6, 409-431, 2008.

Schoch, R. R. and Rubidge, B. S.: The amphibamid Micropholis from the Lystrosaurus Assemblage Zone of South Africa, J. Vertebr. Paleontol., 25, 502-522, 2005.

Schoch, R. R. and Sues, H.-D.: A new dissorophid temnospondyl from the Lower Permian of north-central Texas, C. R. Palevol, 12, 437-445, 2013.

Sigurdsen, T. and Bolt, J. R.: The Lower Permian amphibamid Doleserpeton (Temnospondyli: Dissorophoidea), the interrelationships of amphibamids, and the origin of modern amphibians, J. Vertebr. Paleontol., 30, 1360-1377, 2010.

Sigurdsen, T. and Green, D. M.: The origin of modern amphibians: a re-evaluation, Zool. J. Linn. Soc.-Lond., 162, 457-469, 2011.

Sullivan, C. and Reisz, R. R.: First record of Seymouria (Vertebrata: Seymouriamorpha) from Early Permian fissure fills at Richard Spur, Oklahoma, Can. J. Earth Sci., 36, 1257-1266, 1999.

Sullivan, C., Reisz, R. R., and May, W. J.: Large Dissorophoid Skeletal Elements from the Lower Permian Richards Spur Fissures, Oklahoma, and Their Paleoecological Implications, J. Vertebr. Paleontol., 20, 456-461, 2000.

Werneburg, R.: Apateon dracyiensis - eine frühe Pionierform der Branchiosaurier aus dem europäischen Rotliegend, Teil 1: Morphologie, Veröffentlichungen des Naturhistorischen Museum Schleusingen, 16, 17-36, 2001.
Werneburg, R.: Apateon dracyiensis - eine frühe Pionierform aus dem europäischen Rotliegend, Teil 2: Paläoökologie, Veröffentlichungen des Naturhistorischen Museum Schleusingen, 17, 17-32, 2002.

Werneburg, R.: The branchiosaurid amphibians from the Lower Permian of Buxières-les.Mines, Bourbon l'Archambault Basin (Allier, France) and their biostratigraphic significance, Bulletin Societé géologique Francais, 174, 343-349, 2003.

Williston, S. W.: Cacops, Desmospondylus; new genera of Permian vertebrates, Bull. Geol. Soc. Am., 21, 249-284, 1910.

Williston, S. W.: American Permian vertebrates, The University of Chicago Press, Chicago, 1911.

Witzmann, F. and Pfretzschner, H.-U.: Larval ontogeny of $\mathrm{Mi}$ cromelerpeton credneri (Temnospondyli, Dissorophoidea), J. Vertebr. Paleontol., 23, 750-768, 2003.

Witzmann, F. and Schoch, R. R.: The postcranium of Archegosaurus decheni, and a phylogenetic analysis of temnospondyl postcrania, Palaeontology, 49, 1211-1235, 2006a.

Witzmann, F. and Schoch, R. R.: Skeletal development of the temnospondyl Acanthostomatops vorax from the Lower Permian Döhlen Basin of Saxony, T. RSE Earth, 96, 365-385, 2006b.

Woodhead, J., Reisz, R., Fox, D., Drysdale, R., Hellstrom, J., Maas, R., Cheng, H., and Edwards, R. L.: Speleothem climate records from deep time? Exploring the potential with an example from the Permian, Geology, 38, 455-458, 2010. 